\title{
Influence of Atropine upon the Reduction of Epinephrine Content of the Suprarenal Gland, due to Certain Agencies.
}

\author{
By \\ Naosi Sazawa. \\ (佐濢直) \\ (From the Physiological Laboratory of Prof. Y. Satake, \\ Tohoku Imperial University, Sendai.)
}

The view of Kurél) that the spinal parasympathetic nervous fibres control the secretion of epinephrine from the suprarenal capsule, and the sympathetic fibres only its production, is supported by the atropine experiments of $\mathrm{Y}$. Wada. ${ }^{12}$ ) When atropinized, the epinephrine load increases on applying some agencies, for example bleeding, stimulating the splanchnic nerves, which act also to reduce the load.

The results of bleeding experiments of Wada contradict the previous finding of $\mathrm{K}$. Takahashi, who was able to find no effect of atropine upon reduction of the epinephrine load causable by bleeding. ${ }^{3)}$ That atropine itself acts to accelerate the epinephrine discharge and never to interfere with its acceleration by insulin or morphine has been also established in this Laboratory.)

The discrepancies in the experimental results above related, have led me to attempt to investigate the epinephrine content of the suprarenals of the rabbits under influence of atropine on applying stimulation on the splanchnic nerves, bleeding and insulin.

1) Ku ré, Ueber den Spinalparasympathikus, 1931 Basel, 48 ff.; K u ré, Y. W a d a and $\mathrm{Okinaka,Q.} \mathrm{J.} \mathrm{of} \mathrm{Exp.} \mathrm{Physiol.,} \mathrm{1982,} \mathrm{21,} 227$.

2) Y. W a d a, Tokyo Igakkai Zassi, 1932, 46, 1815.

3) K. Takahas hi, Hokuetu Igakkai Zassi, 1922, 37, 257.

4) H. Sato, Hata no and Mu to, Tohoku J. of Exp. Med., 1938, 34, 289 \& 393. 
Suto-Kojima's corrosive sublimate method was used for estimating epinephrine in the suprarenal gland.

\section{(1) Stimulating the splanchnic nerves.}

A rabbit was fastened, the abdominal cavity opened, and the left splanchnic was cut and its peripheral part was stimulated electrically for 5-10 minutes, 2 volts battery and $7-10 \mathrm{cms}$. coil distance being used. It was a little stronger than being perceivably felt on the tip of the tongue. After the stimulation, both suprarenal glands were extirpated. All manipulations consumed about 15-20 minutes; no anaesthesia was used.

The epinephrine content in the left stimulated gland, 24 in number, was mean $0.44 \mathrm{mgrm}$. per grm. gland (0.27-0.64 mgrm.) or $0.03 \mathrm{mgrm}$. per kilo of body weight (0.018-0.053) and that in the right gland with intact innervation $0.51 \mathrm{mgrm}$. per grm. gland (0.28-0.82 mgrm.) or 0.033 mgrm. per kilo (0.018-0.059).

On an average, the gland on the left stimulated side was found containing a somewhat smaller amount of epinephrine in comparison with the fellow gland, with intact innervation. The figures from case to case never contradicted this tendency, that is, the content in the left gland was either somewhat smaller than, or wholly the same as the right gland. The content of the right gland was also reduced in the experimental conditions as these, as is to be expected. The values in the normal control rabbits ${ }^{5}$ are for the right gland with intact innervation $0.67 \mathrm{mgrm}$. per grm. gland (0.27-0.94). And the values in rabbits which were treated in a similar manner to the present, but a somewhat longer interval being allowed to elapse till killing, were somewhat smaller, that is $0.46 \mathrm{mgrm}$. per grm. gland (0.25-0.59).

That stimulation of the splanchnic nerve usually causes a reduction in the epinephrine content has been proved by several experimentalists, especially in the case of rabbits, ${ }^{6}$ though it does so only with difficulties in other species of animals, such as cats, dogs.?)

5) S a z aw a, Tohoku J. of Exp. Med., 1938, 34, 277.

6). Kahn, Pflüger's Arch., 1911, 140, 245 f.; Takahashi, Hokuetsu Igakkai, Zassi, 1922, 37, 273 t. ; Mor ita, Fukuoka Ikadaigaku Zassi, 1923, 16, 32 f. ; I m a mu ra, Keiō Igaku, 1924, 4, 1277 f.; A b e, ibid., 1927, 7, 681 f.

7) Tscheboksar off, Pfüger's Arch., $1910(-11)$, 137, $92 \mathrm{f}$. (Dog); Elliott, J. of Physiol., 1912, 44, $396 \mathrm{f}$. (Cat); Stewart and Rogoff, J. of Exp. Med., 1916, 24, 732 f. (Cat); W ad a, Tokyo Ikadaigaku Zassi, 1932, 46, 1845 f. (Dog). 
TABLE I.

Epinephrine content estimated by the Suto-Kojima's method in the suprarenal glands of rabbits, in which the left splanchnic nerve was stimulated for 5-10 minutes under non-anaesthesia.

\begin{tabular}{|c|c|c|c|c|c|c|c|c|c|c|c|c|}
\hline \multirow{3}{*}{ No. } & \multirow{3}{*}{ Sex } & \multirow{3}{*}{ 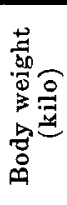 } & \multirow{2}{*}{\multicolumn{2}{|c|}{$\begin{array}{c}\text { Weight of } \\
\text { suprarenal } \\
\text { gland } \\
\text { (mgrm.) }\end{array}$}} & \multicolumn{6}{|c|}{ Epinephrine content (mgrm.) } & \multicolumn{2}{|c|}{$\begin{array}{l}\text { Quantity } \\
\text { of atropine }\end{array}$} \\
\hline & & & & & \multicolumn{2}{|c|}{ per gland } & \multicolumn{2}{|c|}{$\begin{array}{l}\text { per grm. } \\
\text { gland }\end{array}$} & \multicolumn{2}{|c|}{$\begin{array}{c}\text { per kilo } \\
\text { body weight }\end{array}$} & \multirow{2}{*}{ 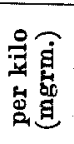 } & \multirow{2}{*}{ 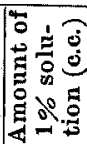 } \\
\hline & & & $\mathbf{L}$ & $\mathbf{R}$ & $\mathrm{L}$ & $\mathbf{R}$ & $L$ & $\mathbf{R}$ & $\mathbf{L}$ & $\mathrm{R}$ & & \\
\hline & & A. & \multicolumn{4}{|c|}{ Control experiments. } & & & & & & \\
\hline 1 & 우 & 1.83 & 104 & 85 & 0.051 & 0.049 & 0.49 & 0.59 & 0.028 & 0.027 & & \\
\hline 2 & 우 & 1.83 & 88 & 82 & 0.055 & 0.052 & 0.63 & 0.63 & 0.030 & 0.028 & & \\
\hline 3 & $\hat{0}$ & 1.58 & 103 & 85 & 0.037 & 0.040 & 0.36 & 0.47 & 0.023 & 0.025 & & \\
\hline 4 & 우 & 1.48 & 63 & 62 & 0.035 & 0.034 & 0.56 & 0.55 & 0.024 & 0.023 & & \\
\hline 5 & 우 & 1.50 & 73 & 67 & 0.047 & 0.049 & 0.64 & 0.73 & 0.031 & 0.033 & & \\
\hline 6 & 우 & 1.66 & 105 & 99 & 0.042 & 0.037 & 0.40 & 0.37 & 0.025 & 0.022 & & \\
\hline 7 & 우 & 1.66 & 150 & 120 & 0.057 & 0.063 & 0.38 & 0.52 & 0.034 & 0.038 & & \\
\hline 8 & 우 & 2.00 & 125 & 100 & 0.073 & 0.078 & 0.58 & 0.78 & 0.036 & 0.039 & & \\
\hline 9 & 우 & 1.78 & 120 & 117 & 0.041 & 0.042 & 0.34 & 0.36 & 0.023 & 0.024 & & \\
\hline 10 & 우 & 1.70 & 105 & 112 & 0.033 & 0.031 & 0.31 & 0.28 & 0.019 & 0.018 & & \\
\hline 11 & 今 & 2.42 & 158 & 150 & 0.043 & 0.045 & 0.27 & 0.30 & 0.018 & 0.019 & & \\
\hline 12 & 우 & 1.50 & 121 & 100 & 0.067 & 0.076 & 0.55 & 0.76 & 0.045 & 0.051 & & \\
\hline 13 & q & 1.75 & 135 & 118 & 0.051 & 0.055 & 0.38 & 0.47 & 0.029 & 0.031 & & \\
\hline 14 & 우 & 1.55 & 110 & 107 & 0.048 & 0.051 & 0.44 & 0.48 & 0.031 & 0.033 & & \\
\hline 15 & 우 & 1.60 & 122 & 110 & 0.035 & 0.037 & 0.29 & 0.34 & 0.022 & 0.023 & & \\
\hline 16 & 오 & 1.70 & 121 & 121 & 0.051 & 0.065 & 0.42 & 0.54 & 0.030 & 0.038 & & \\
\hline 17 & 우 & 1.47 & 116 & 108 & 0.049 & 0.059 & 0.42 & 0.55 & 0.033 & 0.040 & & \\
\hline 18 & 우 & 1.59 & 135 & 114 & 0.084 & 0.094 & 0.62 & 0.82 & 0.053 & 0.059 & & \\
\hline 19 & $\hat{\delta}$ & 1.40 & 117 & 119 & 0.041 & 0.045 & 0.35 & 0.38 & 0.029 & 0.032 & & \\
\hline 20 & 우 & 1.65 & 148 & 118 & 0.047 & 0.057 & 0.32 & 0.48 & 0.028 & 0.035 & & \\
\hline 21 & 우 & 1.65 & 127 & 127 & 0.073 & 0.077 & 0.57 & 0.61 & 0.044 & 0.047 & & \\
\hline 22 & 今ิ & 1.80 & 132 & 125 & 0.057 & 0.065 & 0.43 & 0.52 & 0.032 & 0.036 & & \\
\hline 23 & 우 & 1.45 & 146 & 142 & 0.048 & 0.051 & 0.33 & 0.36 & 0.033 & 0.035 & & \\
\hline 24 & 우 & 1.30 & 87 & 78 & 0.035 & 0.036 & 0.40 & 0.46 & 0.027 & 0.028 & & \\
\hline \multicolumn{2}{|c|}{ Mean } & 1.66 & \multirow{2}{*}{\multicolumn{4}{|c|}{ Atropine experiments. }} & 0.44 & 0.51 & 0.030 & $\mathbf{0 . 0 3 3}$ & & \\
\hline & & B. & & & & & & & & & & \\
\hline 25 & $\delta$ & 1.77 & 101 & 83 & 0.049 & 0.053 & 0.49 & 0.64 & 0.028 & 0.030 & 45 & 8 \\
\hline 26 & q & 1.72 & 101 & 99 & 0.077 & 0.073 & 0.76 & 0.74 & 0.045 & 0.042 & 46 & 8 \\
\hline 27 & 우 & 1.84 & 141 & 120 & 0.069 & 0.072 & 0.49 & 0.60 & 0.038 & 0.039 & 54 & 10 \\
\hline 28 & 후 & 1.90 & 152 & 129 & 0.055 & 0.055 & 0.36 & 0.43 & 0.029 & 0.029 & 53 & 10 \\
\hline 29 & 우 & 1.50 & 60 & 51 & 0.037 & 0.037 & 0.62 & 0.73 & 0.025 & 0.025 & 53 & 8 \\
\hline 30 & 우 & 1.53 & 68 & 56 & 0.031 & 0.031 & 0.4 & 0.5 & 0.020 & 0.020 & 52 & 8 \\
\hline 31 & 우 & 2.05 & 180 & 160 & 0.097 & 0.098 & 0.54 & 0.61 & 0.047 & 0.048 & 49 & 10 \\
\hline 32 & 웅 & 1.97 & 102 & 97 & 0.045 & 0.043 & 0.44 & 0.44 & 0.023 & 0.022 & 51 & 10 \\
\hline 33 & 우 & 1.70 & 129 & 122 & 0.048 & 0.051 & 0.37 & 0.42 & 0.028 & 0.030 & 59 & 10 \\
\hline 34 & 우 & 1.67 & 125 & 105 & 0.041 & 0.041 & 0.33 & 0.3 & 0.025 & 0.025 & 60 & 10 \\
\hline 35 & 우 & 1.60 & 90 & 75 & 0.061 & 0.054 & 0.68 & 0.72 & 0.038 & 0.034 & 63 & 10 \\
\hline 36 & 우 & 1.70 & 120 & 128 & 0.069 & 0.083 & 0.57 & 0.65 & 0.041 & 0.049 & 59 & 10 \\
\hline 37 & $\hat{\delta}$ & 1.68 & 116 & 111 & 0.036 & 0.044 & 0.31 & 0.40 & 0.021 & 0.026 & 60 & 10 \\
\hline 38 & 우 & 1.70 & 149 & 143 & 0.044 & 0.049 & 0.30 & 0.34 & 0.026 & 0.029 & 59 & 10 \\
\hline 39 & 우 & 1.90 & 186 & 154 & 0.052 & 0.057 & 0.28 & 0.37 & 0.027 & 0.030 & 74 & 14 \\
\hline 40 & 우 & 1.83 & 109 & 118 & 0.035 & 0.037 & 0.32 & 0.31 & 0.019 & 0.020 & 76 & 14 \\
\hline 41 & o & 1.77 & 155 & 143 & 0.050 & 0.053 & 0.32 & 0.37 & 0.028 & 0.030 & 79 & 14 \\
\hline 42 & 1ิ & 1.64 & 98 & 93 & 0.049 & 0.053 & 0.50 & 0.57 & 0.030 & 0.032 & 85 & 14 \\
\hline 43 & 우 & 1.70 & 140 & 111 & 0.039 & 0.040 & 0.28 & 0.36 & 0.023 & 0.023 & 82 & 14 \\
\hline 44 & 全 & 1.50 & 100 & 85 & 0.031 & 0.035 & 0.31 & 0.41 & 0.021 & 0.023 & 67 & 10 \\
\hline 45 & क & 1.30 & 107 & 113 & 0.048 & 0.055 & 0.45 & 0.49 & 0.037 & 0.042 & 61 & 8 \\
\hline \multirow{2}{*}{\multicolumn{2}{|c|}{ Mean }} & 1.30 & 115 & 108 & 0.055 & 0.059 & 0.48 & 0.55 & 0.042 & 0.045 & 61 & 8 \\
\hline & & 1.69 & 120 & 109 & 0.051 & 0.053 & 0.44 & 0.50 & 0.030 & 0.031 & & \\
\hline
\end{tabular}


In another gróup of rabbits, 22 , atropine was injected subcutaneously in a dose of 45-85 mgrms. per kilo, then the animal was fastened, laparotomized and 10-20 minutes after injection of atropine, the left splanchnic nerve was cut and stimulated electrically for 5-10 minutes. It was followed by removing the suprarenal glands.

The figures rê the epinephrine content of the suprarenal glands, the glands weight and the body weight in this group of atropinized rabbits were quite the same as those in the non-atropinized rabbits, as seen from the accompanying table at a glance. It may be added that there was no case where the right gland had a smaller amount of epinephrine than the left stimulated gland.

It is therefore impossible to see an excess in the epinephrine load in the group of atropinized animals.

The figures presented by Wada must be taken,, ${ }^{1,2)}$ generally speaking, as showing an increase of the epinephrine content in the gland on the stimulated side. But it may be pointed out that the outcome of his work was not so uniform although it is, somewhat difficult to see what were the real figures in comparing those two papers, the English and the Japanese. In the English paper it is written in the text as if there was only an exceptional case, but if one examines Table III, one will soon find three cases where the epinephrine load was smaller in the left gland, in which side, according to the text, the great splanchnic was stimulated. The difference in No. 7 was too small to speak of ; but if so, this must be taken as to contradict his view. (The calculation rê epinephrine content per grm. gland in the English paper is erroneous or a misprint; it is given correctly in the Japanese paper.) According to the Japanese paper, the right splanchnic was stimulated in Nos. $6,7 \& 8$ (in the English paper) $(7,8 \& 9$ in the Japanese paper) instead of the left; and in that paper two additional cases (Nos. $10 \& 12$ ) are given. The data given in the Japanese paper records that there are 6 cases where the epinephrine load in the side that had been stimulated was greater than the opposite side, 3 cases with a wholly reverse outcome, and 1 case with a similar load in both glands. The last case should be taken also as exceptional. The negative cases are therefore too many for establishing his view.

\section{(2) Bleeding.}

It is a well established fact that bleeding produces a reduction in the epinephrine storage. ${ }^{8)}$

8) Ta chi, Tohoku J. of Exp. Med., 1928, 10, 409. Literature there. 
TABLE

Epinephrine content estimated by the Suto-Kojima's method in

\begin{tabular}{|c|c|c|c|c|c|c|c|c|c|c|}
\hline \multirow{3}{*}{ No. } & \multirow{3}{*}{ Sex } & \multirow{3}{*}{$\begin{array}{l}\text { Body } \\
\text { weight } \\
\text { (kilo) }\end{array}$} & \multirow{2}{*}{\multicolumn{2}{|c|}{$\begin{array}{c}\text { Suprarenal } \\
\text { weight } \\
\text { (mgrm.) }\end{array}$}} & \multicolumn{6}{|c|}{ Epinephrine content (mgrm.) } \\
\hline & & & & & \multicolumn{2}{|c|}{ per gland } & \multicolumn{2}{|c|}{$\begin{array}{l}\text { per grm. } \\
\text { gland }\end{array}$} & \multicolumn{2}{|c|}{$\begin{array}{c}\text { per kilo } \\
\text { body weight }\end{array}$} \\
\hline & & & $\mathrm{L}$ & $\mathrm{R}$ & $\mathrm{L}$ & $\mathbf{R}$ & $\mathbf{L}$ & $\mathbf{R}$ & $\mathbf{L}$ & $\mathbf{R}$ \\
\hline 47 & 우 & 1.71 & 60 & 58 & 0.045 & 0.045 & 0.75 & 0.78 & 0.026 & 0.026 \\
\hline 48 & 우 & 1.60 & 63 & 52 & 0.031 & 0.034 & 0.49 & 0.65 & 0.019 & 0.021 \\
\hline 49 & f & 1.45 & 90 & 77 & 0.046 & 0.054 & 0.51 & 0.70 & 0.032 & 0.037 \\
\hline 50 & 우 & 1.33 & 64 & 55 & 0.045 & 0.040 & 0.70 & 0.73 & 0.034 & 0.030 \\
\hline 51 & 우 & 1.66 & 73 & 69 & 0.043 & 0.056 & 0.59 & 0.81 & 0.026 & 0.084 \\
\hline 52 & 우 & 2.26 & 178 & 171 & 0.064 & 0.059 & 0.36 & 0.35 & 0.028 & 0.026 \\
\hline \multicolumn{2}{|c|}{ Mean } & 1.67 & 88 & 80 & 0.046 & 0.048 & 0.57 & 0.67 & 0.027 & 0.029 \\
\hline
\end{tabular}

The finding of $\mathrm{Hara}^{9)}$ that repeated bleedings bring about a remarkable increase in the epinephrine load needs to be re-investigated. He removed in two rabbits the left suprarenal gland, then, in two weeks, bleeding of one third of the blood volume was conducted several times. The right gland was found having become lighter and containing a greater amount of epinephrine in comparison to the fellow, removed previously. In Rabbit No. 11, L 0.183 grm., $0.0537 \mathrm{mgrm}$. per gland, $0.2934 \mathrm{mgrm}$. per grm. gland, R 0.164 grm., $0.1318 \mathrm{mgrm}$. \& $0.8036 \mathrm{mgrm}$. and in No. 12 , L $0.3283 \mathrm{grm} ., 0.1227 \mathrm{mgrm}$. \& $0.3731 \mathrm{mgrm}$., $\mathbf{R} 0.2825 \mathrm{grm} ., 0.222 \mathrm{mgrm}$. \& $0.7858 \mathrm{mgrm}$. If these figures be compared with those in the left gland which was removed in the same manner as the above, one must doubt the validity of his conclusion. The content of the left gland in 7 rabbits was $0.075-0.2001$, mean $0.12 \mathrm{mgrm}$. in toto and $0.5-1.297 \mathrm{mgrm}$. per grm. gland, mean $0.75 \mathrm{mgrm}$. (The values, given in the table on p. 985 as the content per 10 grms. gland should be that per grm., except No. 28.) We see a rather small value in the left gland in the two rabbits bled several times, and no abnormally large value in the right gland, removed after bleeding several times. There is no indication of how many times bleeding was carried out, and when the right gland was removed after the last bleeding. While the author wrote of a reduction in the body weight, it is difficult to see it from the table on p. 987.

Although the view that repetition of bleeding elicits an overload of epinephrine harmonizes with the effect of repeated application of insulin, ${ }^{10}$ the evidence afforded by $\mathrm{H}$ ara cannot be looked upon as adequate; further investigations are desirable.

9) Yu. Hara, Nihon Gekagakkai Zassi, 1923-24, 24, 973.

10) Z. Kanowoka, Tohoku J. of Ex. Med, 1935, 25, 97 (Previous references there.). 
II.

the suprarenal glands of atropinized rabbits after bleeding.

\begin{tabular}{|c|c|c|c|c|c|c|c|c|c|}
\hline \multicolumn{2}{|c|}{ Bleeding } & \multicolumn{8}{|c|}{ Atropine } \\
\hline $\begin{array}{l}\text { total } \\
\text { (c.c.) }\end{array}$ & $\begin{array}{c}\text { per } \\
\text { kilo } \\
\text { (c.c.) }\end{array}$ & $\begin{array}{c}\text { dura- } \\
\text { tion of } \\
\text { bleeding } \\
\text { (min.) }\end{array}$ & $\begin{array}{l}\text { solu- } \\
\text { tion } \\
(\%)\end{array}$ & $\begin{array}{c}\text { injected } \\
\text { before } \\
\text { bleeding } \\
\text { (c.c.) }\end{array}$ & $\begin{array}{c}\text { injected } \\
\text { after } \\
\text { bleeding } \\
\text { (c.c.) }\end{array}$ & $\begin{array}{c}\text { total } \\
\text { (mgrm.) }\end{array}$ & $\left(\begin{array}{c}\text { per } \\
\text { kilo } \\
\text { (mgrm. }\end{array}\right.$ & $\begin{array}{l}\text { dura- } \\
\text { tion of } \\
\text { poison- } \\
\text { ing } \\
\text { (hour) }\end{array}$ & $\begin{array}{c}\text { symp } \\
\text { toms } \\
\text { after } \\
\text { bl. }\end{array}$ \\
\hline 36 & 21 & 5 & 1 & 6 & 3 & 90 & 53 & $4 \frac{1}{6}$ & \pm \\
\hline 43 & 27 & 10 & 1 & 7 & 3 & 100 & 62 & 43 & + \\
\hline 35 & $\mathbf{2 4}$ & 5 & 1 & 10 & 6 & 160 & 110 & $3 \frac{5}{6}$ & \pm \\
\hline 30 & 23 & 7 & 1 & 9 & 3 & 120 & 90 & $6 \frac{2}{3}$ & \pm \\
\hline 37 & 22 & 17 & 1 & 10 & 3 & 180 & 78 & $6 \frac{1}{3}$ & \pm \\
\hline 53 & 23 & 10 & 2 & 8 & 6 & 280 & 124 & $3 \frac{1}{12}$ & ++ \\
\hline
\end{tabular}

While Takahas $\mathrm{hi}^{3}$ was unable to find any influence of atropine upon the epinephrine depletion due to haemorrhage, $\mathrm{W} \mathrm{a} \mathrm{d} \mathrm{a}{ }^{11)}$ believes atropine nullifies the reducing effect of haemorrhage on the epinephrine storage.

In 4 rabbits of 1.6-2 kilos, Takahashi bled 15-30 c.c. blood 40-60 minutes after atropinizing, and 15 minutes to 1.5 hours later the animals were killed. Both glands, combined, contained mean $0.1213 \mathrm{mgrm}$. in total (0.1014$0.1348 \mathrm{mgrm}$.) and mean $0.0645 \mathrm{mgrm}$. per kilo (0.0578-0.0693 mgrm.). These figures are definitely inferior to the normal controls, mean $0.1477 \mathrm{mgrm}$. in toto and 0.0825 per kilo. In 10 rabbits of $1.7-2.3$ kilos, Takahashi shed 25-40 c.c. blood and 15 minutes to 3 hours later the glands contained mean $0.0913 \mathrm{mgrm}$. (0.0436-0.1236 mgrm.) in toto and $0.0475 \mathrm{mgrm}$. per kilo $(0.0223$ $0.0613 \mathrm{mgrm}$.). These figures are smaller, but their smallness is due to the rabbits being killed 2-3 hours after bleeding; if they be for the time being omitted from considation, the figures are $0.11 \mathrm{mgrm}$. in toto and $0.055 \mathrm{mgrm}$. per kilo and similar to those in the atropinized animals. Exact comparison is difficult because of dissimilarities in both sets of experiments despite the relatively smallness of experiments.

$\mathrm{W}$ a d a injected into 4 dogs atropine in separate doses ( 2 or 3 times, each time 2 or 3 c.c.), and meanwhile $200.0,270.0$ c.c. blood were shed ; this corresponds to $1: 25-30$ of the body weight. $\left.{ }^{11}\right) 22$ to 50 minutes later the animals were killed; the glands were found containing $1.04 \mathrm{mgrm} .(0.98-1.24 \mathrm{mgrm}$.) in toto and 1.4 mgrms. (1.11-1.79 mgrms.) per grm. gland. These figures are definite-

11) Y. Wada, Tokyo Igakkai Zassi, 1932, 46, 1815; Kuré, Wada and Okinaka, Q. J. of Exp. Physiol., 1932, 21, 227. 
ly larger than those of his own control animals and those of Morita, ${ }^{12}$ quoted there. In 2 rabbits he carried out a similar research; atropine was applied in the same dose per animal, and blood corresponding to about 1:5070 of body weight was shed, 20 or 28 minutes later the animals were killed. The content was $0.2 \mathrm{mgrm}$. in both glands in both cases, which corresponds to $0.91 \mathrm{mgrm}$. and $0.62 \mathrm{mgrm}$. per grm. gland. The epinephrine content of the normal control rabbits, estimated some years later by another experimentalist in the same laboratory, ${ }^{13 i}$ was about $0.1 \mathrm{mgrm}$. in the right gland, which corresponds to $0.6 \mathrm{mgrm}$. per grm.

In three dogs Y. Wada opened the abdominal cavity, ${ }^{12}$ followed by sectioning one side splanchnic nerve, then blood volume corresponding 1:3045 of body weight was shed. 50-60 minutes later the animals were killed, the gland, intactly innervated, contained a smaller amount of epinephrine than the denervated fellow. The values in the former are however measured by Wad a himself in the normal animals, and those of the denervated gland in two out of three dogs exceed clearly the normal controls. He looks upon this latter fact as the new production through the coeliac ganglia.

The discrepancy in the results of Takahashi on the one side and of Wada on the other has led me to carry out the following experiments. Rabbits, 6 in number, were poisoned with repeated subcutaneous injection of atropine, or they were for about 3-7 hours under influence of atropine, and meanwhile blood was taken out from a carotid artery in amounts varying from 21 to 27 c.c. per kilo of body weight, and usually one and a half hours later the animals were killed promptly, and the suprarenal capsules were estimated for epinephrine.

An example may be cited here.

No. 47. 1.71 kilos 우

1 c.c. $1 \%$ atropine-Tyrode at each injection subcutaneously injected with 30 minutes interval, which was repeated 9 times making 53 mgrms. per kilo. 5 minutes after the 6 th injection of atropine 36 c.c. blood, viz. 21 c.c. per kilo, were shed from the right carotid during 5 minutes. Symptoms slight. 10 minutes after the last injection, that is one and a half hours after bleeding, the animal was killed by a blow on the nape of the neck.

About the same amount of blood, reckoned on the body weight was shed in these six animals, but two (Nos. $48 \& 52$ ) suffered seriously therefrom, wholly weak, especially No. 52 was not capable of standing by itself for one hour, and when seeming to begin recovery, it was killed, that is $1 \frac{1}{4}$ hours after bleeding; in the rest they were killed exactly $1 \frac{1}{2}$ hours after bleeding.

12) Morita, Fukuoka Ikadaigaku Zassi, 1923, 16, 1.

13) Ya ma moto, Tokyo Igakkai Zassi, 1935, 49, 437. 
The estimates rê the epinephrine are given in Table II. If they be compared to the normal control, given for example in our previous paper, ${ }^{5)}$ it is impossible to mention of any increase, and if the total amount be reckoned on the body weight, a remarkable reduction is readily detectable, especially in both cases where bleeding was attended by the appearance of serious clinical symptoms. The gland weight was measured reduced in these cases, consequently the content reckoned per grm. gland showed no noticeable changes from the controls. The reduction in the weight was very large, that is the gland weights both together were per kilo of body weight 69-115 mgrms. in 5 cases and 155 mgrms. in a single case (No. 52), in contrast to about 150-200 mgrms. in normal rabbits. ${ }^{14)}$

A reduction in the suprarenal body after bleeding was only just visible in the experiments of Takahashi, above cited; or almost nothing in Tachi.8) The glands weight per kilo body weight in 10 normal rabbits was 180 mgrms, that in 10 bleeding experiments, 153 mgrms. In the repeated bleeding experiments, Hara noted a reduction in the gland weight, but not considerably so. However, the reduction was detectable in one of two rabbits in $\mathrm{W}$ ad a which was poisoned with atropine and bled. If reckoned on the weight of the gland, the epinephrine content in that rabbit of $\mathrm{W}$ a d a can be taken as having increased; but the epinephrine content in toto in two rabbits, $0.100 \mathrm{mgrm}$. in all four glands, does not exceed the normal limits, given, for instance, in the papers of Morita ${ }^{12)}$ and of Yamamoto. ${ }^{13)}$

The interval of time which was allowed to elapse in the rabbit experiments of Wa da from bleeding to killing, was 28 and 20 minutes ; while the reduction of epinephrine in the rabbits of Takahashi was decidedly larger 2-3 hours after haemorrhage than in the cases killed 15-40 minutes after it. In the present experiments a one and a half hour period was the interval between bleeding and killing, the data ${ }^{15}$ ) rê the blood sugar and epinephrine secretion being taken into account.

\section{(3) Insulin.}

Insulin acts to accelerate the discharge of epinephrine from the suprarenal capsule ${ }^{16)}$ through the central mechanism. ${ }^{17)}$ And the

14) Ko jim a, Tohoku J. of Exp. Med., 1929, 13, 212-213.

15) Ta chi, Tohoku J. of Exp. Med., 1928, 10, 96; Saito, Ibid., 1928, 11, 79.

16) Yen, Aomura and Inaba, Tohoku J. of Exp. Med., 1933, 21, 542 . Literature there.

17) Sato, S. Kanowoka and $0 \mathrm{hmi}$, Ibid., 1933, 22, 7. 
TABre

Epinephrine content ( $S$ uto-Kojima's method) in the supraronal

\begin{tabular}{|c|c|c|c|c|c|c|c|c|}
\hline \multirow{3}{*}{ No. } & \multirow{3}{*}{ Sex } & \multirow{3}{*}{$\begin{array}{c}\text { Body } \\
\text { weight } \\
\text { (kilo) }\end{array}$} & \multirow{2}{*}{\multicolumn{2}{|c|}{$\begin{array}{c}\text { Suprarenal } \\
\text { weight } \\
\text { (mgrm.) }\end{array}$}} & \multicolumn{4}{|c|}{ Epinephrine content } \\
\hline & & & & & \multicolumn{2}{|c|}{ per gland } & \multicolumn{2}{|c|}{ per grm. gland } \\
\hline & & & $\mathbf{L}$ & $\mathbf{R}$ & L & $\mathrm{R}$ & L & $\mathbf{R}$ \\
\hline 53 & 今 & 1.69 & 153 & 131 & 0.086 & 0.077 & 0.56 & 0.59 \\
\hline 54 & 우 & 2.14 & 121 & 86 & 0.037 & 0.087 & 0.31 & 0.43 \\
\hline 55 & 우 & 1.86 & 126 & 100 & 0.040 & 0.039 & 0.32 & 0.39 \\
\hline 56 & 우 & 1.72 & 82 & 75 & 0.031 & 0.023 & 0.38 & 0.31 \\
\hline 57 & 우 & 2.13 & 162 & 157 & 0.080 & 0.082 & 0.49 & 0.51 \\
\hline \multicolumn{2}{|c|}{ Mean } & 1.91 & 129 & 110 & 0.055 & 0.052 & 0.41 & 0.45 \\
\hline
\end{tabular}

epinephrine content of the capsule diminishes there, which is protected by sectioning the splanchnic nerves. ${ }^{18)}$ Saito estimated it by means of the Suto-Kojima, the rabbit intestine segment, and the FolinCannon-Denis method.

In the present investigation it has been tested how atropine interferes with the diminishing influence of insulin upon the epinephrine content of suprarenals.

Just as in the foregoing bleeding experiments, rabbits were poisoned with repeated atropine injections; 1 or 2 c.c. of 1 or 2 per cent atropine-Tyrode was injected hypodermically each half hour, which was repeated 11 or 12 times. 65-226 mgrms. atropine sulphate per kilo was given in toto. Insulin-Lilly was given in doses of 3 or 5 units per kilo of body weight, to the fifth injection of atropine, and a half or one hour after the last atropine respectively; just four hours after insulin the animals were killed at once.

Only in a single case No. 56, where insulin was dosaged as 5 units per kilo, convulsions occurred on insulin throughout the observation.

In 3 cases out of 5 the epinephrine content was estimated as reduced, in toto, reckoned on the gland weight or the body weight, especially in the case where convulsive seizures appeared (No. 56). In the remaining cases the epinephrine content was found not reduced, but having remained within the normal limits. In not a single instance was an increase seen.

18) S a it o, Tohoku J. of Exp. Med., 1929, 12, 263. Literature there. 
III.

glands of atropinized rabbits after insulin injection.

\begin{tabular}{|c|c|c|c|c|c|c|c|c|c|}
\hline \multirow{2}{*}{\multicolumn{2}{|c|}{ 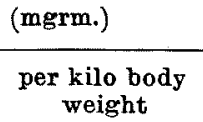 }} & \multicolumn{2}{|c|}{ Insulin } & \multicolumn{6}{|c|}{ Atropine } \\
\hline & & \multirow{2}{*}{$\begin{array}{c}\text { per } \\
\text { kilo } \\
\text { (unit) }\end{array}$} & \multirow{2}{*}{$\begin{array}{c}\text { convul- } \\
\text { sion }\end{array}$} & \multirow{2}{*}{$\begin{array}{c}\text { solu- } \\
\text { tion } \\
(\%)\end{array}$} & \multirow{2}{*}{$\begin{array}{c}\text { before } \\
\text { insulin } \\
\text { (c.c.) }\end{array}$} & \multirow{2}{*}{$\begin{array}{l}\text { after } \\
\text { insulin } \\
\text { (c.c.) }\end{array}$} & \multirow{2}{*}{$\begin{array}{c}\text { total } \\
\text { (mgrm.) }\end{array}$} & \multirow{2}{*}{$\begin{array}{l}\text { per kilo } \\
\text { (mgrm.) }\end{array}$} & \multirow{2}{*}{$\begin{array}{l}\text { duration } \\
\text { of } \\
\text { poison- } \\
\text { ing } \\
\text { (hour) }\end{array}$} \\
\hline$L$ & $\mathbf{R}$ & & & & & & & & \\
\hline 0.051 & 0.046 & 3 & - & 1 & 5 & 6 & 110 & 65 & 6 \\
\hline 0.071 & 0.017 & 3 & - & 1 & 10 & 14 & 240 & 113 & 6 \\
\hline 0.022 & 0.021 & 3 & - & 1 & 5 & 7 & 120 & 65 & 6 \\
\hline 0.018 & 0.013 & 5 & + & 1 & 5 & 7 & 120 & 70 & 6 \\
\hline 0.038 & 0.039 & 5 & - & 2 & 10 & 14 & 480 & 226 & 6 \\
\hline 0.029 & 0.027 & & & & & & & & \\
\hline
\end{tabular}

Similar outcome to the bleeding experiments was also obtainable here with insulin. And the present outcome harmonizes well with that of Sato, Muto and Hatano, that insulin is capable of accelerating the epinephrine output from the suprarenal gland without interference by poisoning with atropine. ${ }^{4)}$

Thus we have failed to duplicate the results of Wad a that application of atropine increases the epinephrine storage of suprarenals when combined with stimulating the cut pheripheral end of the splanchnic nerves or with bleeding, which afford evidences for the view of Kuré that the spinal parasympathetic fibres only convey the secretory impulse towards the suprarenal medulla, whereas the sympathetic fibres coming through the coeliac ganglion the productive impulse.

\section{Summary.*}

We were not able to find that atropine acts to interfere with the reduction of the epinephrine storage in rabbits due to the splanchnic stimulation, to bleeding, or to insulin. Otherwise expressed, we failed here, too, to obtain evidences for the view that only the spinal parasympathetic fibres convey the secretory impulses towards the suprarenal medulla and atropine paralyses their endings.

* On proof reading, it is desired to add here, a recent report of G. A r a ki, Hokuetsu Igakkai Zassi, 1938, 53, 221. Five rabbits were atropinized every day for 189 days with 32.8 grms. atropine in toto. The epinephrine content, determinable by the S u toIn o uye method, was on an average $0.1580 \mathrm{mgrm}$. per gland, $0.252 \mathrm{mgrm}$. per grm. gland and $0.0584 \mathrm{mgrm}$. per kilo body weight, against $0.1832,0.424$ and $0.0749 \mathrm{mgrm}$. in 7 normal rabbits. So he wrote: 'The epinephrine content of suprarenals poisoned repeatedly with atropine was thus clearly reduced'-a correct conclusion, harmonizing 
with ours and all available previous evidences, yet wholly contradicting the data of Kuré.

Notwithstanding that, A r a ki made, curiously enough, a puzzling statement to the following effect: 'Recently, K u ré noted the existence of the spinal parasympathetic nerves, and assumed that the spinal parasympathetic nerves in the splanchnic nerves are also instrumental in bringing about the discharge of epinephrine.

I must accept his view on the ground of my own results, i.e, by repeated injection of atropine, the excitability of the ending of the sympathetic splanchnic nerves is augmented, and that of the parasympathetic is reduced.'

It is necessary to point out that $\mathrm{K} u \mathrm{r}$ é's view is not as quoted by Araki, but is that the parasympathetic fibres in the splanchnic nerves convey only the impulse for the discharge of epinephrine, and the sympathetic only that for its production. 